\title{
Literature, Society And The Writer In Tripartite Unity
}

\author{
Anaso, George Nworah \\ Department of Language and Communication Studies \\ Federal University, Dutsin-ma Katsina State, Nigeria \\ Nwabudike, Christopher Eziafa \\ Department of Language and Communication Studies \\ Federal University, Dutsin-ma Katsina State, Nigeria \\ E-mail: cnwabudike@fudutsinma.edu.ng
}

Doi:10.7575/aiac.alls.v.5n.4p.121

URL: http://dx.doi.org/10.7575/aiac.alls.v.5n.4p.121
Received: 08/06/2014

Accepted: 16/07/2014

\begin{abstract}
The proactive unity of purpose between Literature, society and the writer is the main focus of this paper. Writers use Literature to address various important themes or the goings on in the society, with the purpose of edifying its virtues and condemning the vices so as to adulate the good deeds or correct the society where it goes wrong. However, this role often exposes the writer to danger and risks from vested interests. The paper nevertheless recommends both local and international actions that could be explored to enhance Literature, society and the writer's works. It concludes with the submission that with proper political education, the society would be better placed to choose more responsible leaders so that the lots of the society would be better enhanced. In this way the tripartite unity and the full potentials of Literature and writers in society would be realized.
\end{abstract}

Keywords: Tripartite, pedagogy, Muse, Humanrights, proactive, sycophancy

\section{Introduction}

Literature is defined in various ways by literary scholars. Many definitions of this term are based on its concern with the study of various literary genres and styles. However, at a closer look, Literature is much deeper than this because it involves a good deal of socio and psycho analyses of both an individual and a group of people. Still deeper than these, Literature also touches on such cognate areas as Philosophy, Psychology, History, Sociology, Politics, Religion, Geography and even the sciences. From this angle, the dictionary definition of Literature as the writing or study of works of art (drama, fiction, essays, poetry, biography) or concerned with technical books and journals...(Concise Oxford Dictionary of Current English , 2010: 311-2) is only a part, not a broad definition of what Literature is. Literature is therefore seen as a melting pot of various other disciplines that contribute to its subject of discourse.

From this humble definition of Literature, the discipline can be seen as a prodigious field of study that affects human life and human society greatly. This fact is based on the conception of Literature as a slice of life focusing on the goings-on of the human society, be it fiction or fact.

The literary genres or traditions being considered in this writing concern the poetry, prose, (novel and short story) and drama. The writer or creative artist uses these genres to explore his theme and present his art to the reader (the audience).

\section{The Writer}

Who is the writer? The writer in the context of this paper is the literary artist who uses any of the literary genres to create his work. The writer here therefore concerns himself with the issues of the society, seeking to educate, entertain or edify it. On this basis, Achebe (1975) notes that the writer is:

\section{... A human being with a heightened sensitivity who must be aware of the faintest nuances of injustice in human relations...The writer therefore cannot be unaware of monumental injustice which his people suffer... (pg 75)}

Achebe's view here is that the writer has a keen sense of observation and justice which he applies in scrutinizing his society.

In a deeper sense of commitment, Achebe views the role of the writer in Africa in terms of educating his people. He declares in 'The Novelist as Teacher', The New Statesman; 
perhaps what I write is applied art, as distinct from pure. But who cares? Art is

important, but so is education of the kind I have in mind. $(1965,162)$

Achebe's conception of the role of the writer in Africa is not different from that of most fellow writers.

Close to this keen observatory sensitivity is the feeling of sympathy for his community, which Donald Carter views as a necessary requirement for a writer to be able to reflect objectively on his society:

The novelist does deal with conspicuous suffering,...His people are closer to the edge of experience. He must therefore exercise sympathy before he can exercise art.... (1971:138).

The writer concerns himself with his environment in particular. Considering the African society per se, Eldred Jones (1978) opines that the writer today in Africa:

....must see around him bad politics, bad religion, the misleading of the ordinary people and he is bound to write about all this if he writes about his environment.

...I think the writer must write about what happens around him....

From the above, it is understood that the writer's commitment is with his society or a particular community that the writer chooses to address in a work. For instance, Shakespeare writes in the Elizabethan era and addresses his works to the Renaissance period in Europe. Yet his plays capture the entire Europe although Shakespeare is an English man, Macbeth is set in Scotland, Julius Caesar is set in Italy; the setting of Romeo and Juliet, The Merchant of Venice and The

Tempest is Italy. King Lear captures the English society. The setting of Hamlet, The Prince of Denmark is in the kingdom of Denmark in the Scandinavian region. In some other cases, writers focus on societies not exactly their own original environments to be able to assume the leverage to discuss the universal human issues and human nature objectively and without biases.

Other scholars who have opined on the roles of writers include ken Saro-Wiwa, Ezekiel Mphahlele, Sekou Toure of Guinea, Ushie, Niyi Osundare and Robert Taylor, all given their views on the roles of the writer as a "warrior who should have an opinion on everything from geography, history, physics and chemistry to the fate of mankind" (Mphahlele, 1962).

Sekou Toure's consideration of the role of the African writer is on the basis that:

there is no place outside the African resolution for the artist or the intellectual who is himself concerned with or himself at one with the great battle of Africa and the suffering of humanity (Fanon, 1967).

Along the line of this opinion is that of Ken Saro-Wiwa (1999) who argues that Literature must serve society by steeping itself in politics by interventionist role.

Considering the continent of Africa as a whole, Ushie (2007) views the role of writers alongside other cultural producers to be the front burners:

... Writers have been in the forefront of (among) cultural producers in the fight for the survival and well-being of the prey-Africa. They have fought consistently on the side of the oppressed right from colonial days. (p. 27).

Another scholar, Niyi Osundare, believes that:

A writer in Africa is a person that people look up to, whose work people are trying to see how they relate to the social cultural and political problem (Osundare, 1992:37).

There are other African writers who have passed comments on the role the writer plays in his society. To such commentators, their views are not contradictory to the ones expressed by their non-African counterparts. The view of Robert Taylor (2007), for instance, summarizes the general consensus about the role of the writer in his society:

Anywhere in the globe, the writer is a teacher, entertainer and the looking glass mirror of his society. He not only educates, cautions or gives pleasure, but also shows the society how it looks... (p13).

All these observations are not self-imposed or self-ascribed roles but reflect the intellectual posture and pre-dispositions of the writer in the society.

The views on the role of the writer in his community cannot be said to be exhaustive without the opinion of the Nobelprize laureate, Wole Soyinka, who averred that:

... The artist alone possesses the ability to redeem man from the futility and the horrors that surround him and which he must direct his energies towards eradicating... (Uka 1978: 28)

This opinion shares the optimism of other writers that the role of the writer is achievable and that beholves on the writer to work towards achieving it in order to deliver humanity from total collapse. 


\section{Thematic Concerns of Literary Works}

In all ages and literary genres, Literature deals with the happenings in human society in every land and clime. A survey of Literature across the globe shows that human nature in terms of feelings and emotions appear identical, despite seeming differences in culture. For this reason, there appears to be similarities in writers' handling of various themes. Examples of themes that are readily formed in various literary works across the globe include themes in traditional Literature and prejudice, and others such as politics, religion, greed, sycophancy, war, poverty, rule of impunity, sickness and disease, ethnicity and social class system.

Writers depend or rely heavily on three basic elements to achieve literary creativity, these three elements are:

i. the antecedents of history( or anecdotes);

ii. bthe author's individual personality, and

iii. the influence of the creative spirit (the genius or the Muse). (Anaso, 2007:123/4).

Historical antecedents or anecdotes constitute the incidents that occurred in the past which the writer uses to provide the narrative back-up for his work. He will artistically use them as the framework of his fiction, poem or drama but with little imaginative additions or subtractions here and there. This makes the work a fiction, fact or faction (i.e a combination of the two).

The author's individual personality is established in him by three elements: his natural character imbued in him from birth, the influence of his education, and the influence of his society upon him, acquired in the process of acculturation. These elements help to shape his personality and find expression in his work, dictating his mode of thematic presentation, characterization, setting, language and imagery in expressions.

The third element is the influence of the Muse or the creative spirit (genus) on the writer and informs his creativity in the art. The Muse is simply known as the spirit of inspiration that works with the artistic creator to produce works of great depth and aesthetics in terms of vision and value.

\section{Literature, Writers and Risks in the Society}

Literature and its producers (the writers) like every other profession on earth have their own risks. The first risk or danger confronting literary works arises from its very environment where it is created. Literature is seen to adopt the anti-establish posture in those states or societies with bad governance. As mentioned earlier, Saro-Wiwa observed that; literature must serve the society by steeping itself in politics, which is an interventionist role. Shortly after this comment, he was hanged with eight of his Ogoni co-activists on the charge of treason.

Dictatorial regimes have always seen Literature and their writers as enemies because writers always point out their misrule and show the way ahead for the society, sometimes through revolution as a way of shaking off unpopular governments. In these cases, such regimes devise ways of dealing with the situation: ban the circulation of such antiestablishment works or eliminate their critics or both. Dictators do not want to listen to writers like Robert Bolt when he advises politicians that: 'when statesmen forego their private conscience for the sake of their public duties, they lead their country by short route to chaos' (Bolt 1970:12). Thomas More (as the lord Archbishop of Canterbury) can be said to have saved his society from chaos by refusing to endorse King Henry VIII's bid to divorce the Queen, Catherine of Aragon; although More had to face execution for a trumped up charge of treason. In a similar case in Nigeria, a journalist, Dele Giwa, was on October 19, 1986 assassinated through a letter bomb for daring the ruling powers.

It is perhaps from the consideration of the dangers confronting the writer in his society that Osundare observes that: Africa today is a dangerous place to think, a risky place to argue (1992).

Charles Lawson (2005) has also observed that:

\section{African writers have ended up suffering more indignities, threats, humiliations and genuine terror than their counterparts in the rest of the non-western world (pg 11)}

What this assertion implies is that writers in other places suffer varying degrees of threats, although the African writers are placed in the highest level of risk owing to poor humanright posture of the continent. This is a great hindrance for writers in Africa from practicing their profession. If the themes of the writers in their societies mirror the societies, writers in the advanced world write more on social issues rather than on political corruption, ignorance, poor humanrights and misrule which commonly occur in and engage the attention of their counterparts in Africa. These issues of backwardness continue to endure in the African society because leaders would rather sweep them under the carpet than genuinely attempt to tackle them head on, in the interest of the society, which they lead.

Another issue that poses a great discouragement to writers can be seen as the poor reading habit to literary works by the society. The youths especially are distracted by other activities and their interest is not much on reading. This does not only negatively affect the intellectual growth of the society, but also discourages writers if their works do not sell much. Publishers of literary works are inclined to turn to patronize school texts which they prefer now to literary works because of the tendency to publish and market faster than literary works. In this way, the society is seen to work against itself- derailing its intellectual growth, of discouraging the writers and frustrating their determination to enhance the well-being of the society at large. 


\section{Recommendation}

Literature, society and writer are three elements that work hand in hand for the moral and intellectual advancement of mankind. The writer must be assisted to reflect the true (not the distorted) image of his society, serving as the lookingglass mirror of the society, according to Tailor (2011). In this way, the societal problems can be solved:

$$
\begin{aligned}
& \text {...he (the writer) is the looking-glass or mirror that enables the society see itself } \\
& \text { so as to make corrections or necessary amendments where needed... he must, like } \\
& \text { a seer, caution the society to bring it to the path of rectitude.(p.31) }
\end{aligned}
$$

For this reason, the writer's position in the society is crucial and incontrovertible if the society must be put on the right path of progress. To enhance this tripartite unity of purpose between Literature, Society and the Writer, the following recommendations are advanced:

1. The United Nations Organization (UNO) should decide to tackle the human rights violation in developing countries. This can be monitored through the Humanrights Watch, an organization that observes and reports on human rights violation, and such errant political leaders should be dragged to Hague for judgment and necessary punishment. This issue should be placed above ordinary interference in any nation's internal affairs, but as international action against criminal violation of U.N charter on human-rights;

2. To protect writers from criminal assault against them and their works by dictatorial leaders, writers across the nations in the continent should form a strong and vibrant association that should use their works to protect themselves and their various societies from negative influences of vicious leaders in the various countries;

3. Finally, the societies should be educated by writers on civil liberties and choice of political rulers that should lead them. The society should be educated on the use of electoral process to choose responsible leaders in their various countries and societies. It is this kind of education and social re-generation that Achebe was talking about as his recommendation as the requirement for uplifting humanity.

In addition, educational institutions both at secondary and tertiary levels can help to change the poor reading habit of the society. This can be done by deliberate enforcement of reading works or literary arts among the students, in complementary to the requisite basic curriculum. Students will thereby be constrained to read the literary works not only to pass exams, but also to acquire desired intellectual upliftment.

\section{Conclusion}

This paper has tried to examine the critical relationship among Literature, society and writers, who are viewed as literary artists or creative writers. Literature is deployed by writers to educate the society, who sees writers as their partner in progress and mouth piece. If humanright violation of writers and their works can be properly controlled, most social vices and problems will be proactively addressed and checked, and the society will be a better place for man to live in. Literature and the writers are therefore the established checks for human excesses in the society; as well as the veritable assurance for the survival of mankind and his society.

\section{References}

Achebe, C. (1975). Morning Yet On Creation Day, Essays, London: Oxford University Press, Heinemann.

Achebe, C. (1965). The Novelist as Teacher, London: New Statesman.

Anaso, G.N. (2007).Literature as Social Discourse: A Case Study of Social and Ideological Dimensions of Conflict in the Selected Novels of Chinua Achebe and Timothy.

M. Aluko, a PhD project in the Department of English and Literary Studies, Ahmadu Bello University, Zaria.

Bolt, R. (1970). A Man for all Seasons, London: Heinemann.

Carter, D. (1971). Sympathy and Art: Novels and Short Stories in African Literature today.

Fanon, E (1967). The Wretched Of the Earth, GE. Britain: Penguin.

Honby A.S. (2010ed.). Oxford Advanced English Dictionary of Current English. New 7th Edition, O.U.P.

Jones, E. (1973).'Locale and Universe: Three Nigerian novels'. Journal Of Literature ed. By James Curreu.

Larson, C (2007). The Deal of the African Writer, London, New York: ZED Books.

Mphahlele, E. (1982). The African Image, London, Heinemann.

New Swan Books. (1972). “Complete Works of Shakespeare”, (2 ${ }^{\text {nd }}$ Ed,) London: Swan press.

Osundare, N. (1992). Great African on the Record, A Dictionary of African Quotation (ed.) V. Omuabo; Lagos.

Saro-Wiwa, K (1999). A Month and a Day, Detention Diary, Ibadan: Spectrum

Tailor, R.B (2011). Looking into Literatures and Themes: A Critical Appraisal, Ibadan: Abbey Press.

Uka, K. (1978). 'From Commitment to Essence, ( A View of African Writting)', Literature and Modern West African Culture (ed) D. I. Nwuga, Benin City: Ethiope Publishing Corporation.

Ushie, J. A. (2001) 'Many Voices, Many Visions': a Stylistic Study of New African poetry, Faculty of Arts, University of Ibadan, Nigeria. 